\title{
Nuclear receptor-mediated hepatomegaly and liver regeneration: an update
}

\author{
Pengfei Zhao ${ }^{1 \#}$, Shicheng Fan $^{1 \#}$, Yue Gao ${ }^{1 \#}$, Min Huang ${ }^{1}$, Huichang Bi $^{1,2 *}$ \\ ${ }^{1}$ Guangdong Provincial Key Laboratory of New Drug Design and Evaluation, School \\ of Pharmaceutical Sciences, Sun Yat-sen University, Guangzhou, 510006, China \\ ${ }^{2}$ NMPA Key Laboratory for Research and Evaluation of Drug Metabolism, School of \\ Pharmaceutical Sciences, Southern Medical University, Guangzhou, 510515, China
}

\#: These authors contributed equally to this work. 
Running Title: NR-induced hepatomegaly and liver regeneration

*Correspondence to: Huichang Bi, Ph.D. School of Pharmaceutical Sciences, Sun

Yat-sen University and Southern Medical University, 132\# Waihuandong Road,

Guangzhou University City, Guangzhou 510006, P. R. China.

Email: bihchang@mail.sysu.edu.cn or bihchang@mail.smu.edu.cn.

Phone: +86-20-61648530.

Fax: +86-20-39943000

The number of text pages: 42

The number of tables: 3

The number of figures: 3

The number of references: 131

The number of words in the Abstract: 77

The number of words in the Introduction: 908

The number of words in the Discussion: 1171 


\section{Abbreviations}

AKT: protein kinase B; BEC: biliary epithelial cells; CAR: constitutive androstane receptor; CITCO: (6-(4-chlorophenyl) imidazo[2,1-b][1,3]thiazole-5-carbaldehydeO-(3,4-dichlorobenzyl)oxime); CTNNB1: $\beta$-Catenin; CV: central vein; DBD: DNA-binding domain; FXR: farnesoid X receptor;

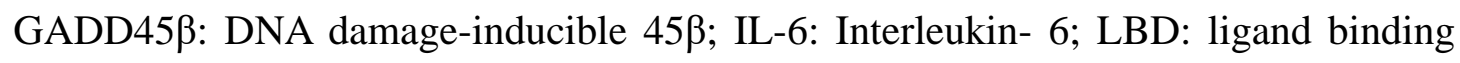
domain; LPCs: liver progenitor cells; LXR: liver X receptor; MAPK: mitogen activated protein kinase; MET: mesenchymal epithelial transition factor receptor; NF- $\mathrm{BB}$ : nuclear factor kappa-B; NRs: nuclear receptors; OCA: obeticholic acid; PCN: pregnenolone-16 $\alpha$-carbonitrile; PHx: partial hepatectomy; PI3K: phosphatidylinositol 3-kinase; PPAR: peroxisome proliferators-activated receptor; PTEN: phosphatase and tensin homologue; PV: portal vein; PXR: pregnane $\mathrm{X}$ receptor; $\mathrm{RXR} \alpha$ : retinoid $\mathrm{X}$ receptor $\alpha$; SFSS: small-for-size-syndrome; STAT3: signal transducer and activator of transcription 3; TCPOBOP: 1,4-bis [2(3,5-dichloropyridyloxy)] benzene; TEAD: TEA domain family member; TNF- $\alpha$ : tumor necrosis factor $\alpha$; YAP: yes-associated protein. 


\begin{abstract}
Nuclear receptors (NRs), a superfamily of ligand-activated transcription factors, are critical in cell growth, proliferation, differentiation, metabolism, and numerous biological events. NRs have been reported to play important roles in hepatomegaly (liver enlargement) and liver regeneration by regulating target genes or interacting with other signals. In this review, the roles and involved molecular mechanisms of NRs in hepatomegaly and liver regeneration are summarized and the future perspectives of NRs in the treatment of liver diseases are discussed.
\end{abstract}

\title{
Keywords
}

Nuclear receptors, Hepatomegaly, Liver regeneration, Pregnane X receptor, Constitutive androstane receptor, Farnesoid $\mathrm{X}$ receptor, Peroxisome proliferators-activated receptor, Liver X receptor

\section{Significance statement}

NRs play critical roles in hepatomegaly and liver regeneration, indicating the potential of NRs as targets to promote liver repair after liver injury. This paper reviews the characteristics and molecular mechanisms of NRs in regulating hepatomegaly and liver regeneration, providing more evidence for NRs in the treatment of related liver diseases. 


\section{INTRODUCTION}

Liver possesses many physiological functions in mammals, such as metabolism and detoxification. A constant size and mass is critical for liver to exert its functions (Michalopoulos, 2017). Under normal conditions, liver maintains the relative liver weight and hepatocyte numbers by preprogrammed processes. Hepatomegaly (liver enlargement) refers to increased liver mass, enlarged hepatocyte size, hyperproliferation, and increased activity of metabolizing enzymes which modulates the metabolism of endobiotics and xenobiotics such as kinds of drugs (Zhao et al., 2021), which can be characterized by hepatocyte hypertrophy and hyperplasia. Hypertrophic process refers to the increase volume of hepatocyte, and hyperplasia process refers to the hepatocellular proliferation process (Ross et al., 2010). Hepatomegaly can be induced by numerous factors such as alcohol, drug, viral hepatitis, tumor, hormone, inflammation, excessive nutrition, fatty liver, etc (Wolf and Lavine, 2000). Besides, hepatomegaly may be induced by primary liver diseases or might be involved secondly in diseases elsewhere in the body (Kaude and Deland, 1975). It can be divided into two types: adverse hepatomegaly and non-adverse hepatomegaly (benign hepatomegaly). Non-adverse hepatomegaly is always induced by drugs or chemicals and would recover after withdrawal (Hall et al., 2012a). The way to distinguish these two types of hepatomegaly is to evaluate the clinic pathological evidence of some biochemical indicators related to liver injury (Hall et al., 2012a).

Liver regeneration is an adaptive response induced by specific stimuli, including 
continuous changes in morphological reconstruction and gene expression. Various extrinsic and intrinsic factors are involved in liver regeneration (Forbes and Newsome, 2016). The introduction of partial hepatectomy (PHx) model in 1931 greatly promoted the studies on liver regeneration (Higgins and Anderson, 1931). Liver regeneration consists of a variety of stages, mainly including three stages: hepatocytes transition into G1 phase once PHx happens, then followed with S phase in 12-15 h, and hepatocytes enter G2 phase about 6-8 h after S phase (Court et al., 2002). Liver regeneration consists of quickly induction of proliferation factors to activate quiescent hepatocytes and start the subsequent process in the cell cycle, acceleration of the recovery of normal liver size and reconstruction of hepatocyte quiescence (Fausto, 2000). Hepatocyte hypertrophy is the first stage of liver regeneration post $70 \% \mathrm{PHx}$, in fact, it is sufficient for hepatocyte hypertrophy to promote the recovery of liver mass after 30\% PHx (Miyaoka et al., 2012). After that, hepatocytes proliferation begins, which is stimulated by hepatocytes and bile duct epithelial cells to deal with functional defects (Malato et al., 2011). Previous studies demonstrated that various signaling pathways participated in liver regeneration. At the very beginning of the liver regeneration, cytokines including interleukin-6 (IL-6) and tumor necrosis factor $(\mathrm{TNF}-\alpha)$ can activate nuclear factor kappa-B (NF- $\kappa \mathrm{B})$ and signal transducer and activator of transcription 3 (STAT3), then the hepatocyte proliferation process is induced (Taub, 2004). In addition, some growth factors also take part in the liver regeneration. Hepatocyte growth factor can activate phosphatidylinositol 3-kinase $(\mathrm{PI} 3 \mathrm{~K}) /$ protein kinase $\mathrm{B}(\mathrm{AKT})$ as well as extracellular-regulated kinase pathway to 
promote DNA replication and hepatocyte proliferation (Taub, 2004). MicroRNAs such as miRNA-21 participate in the regulation of liver regeneration process (Chen et al., 2016). Liver progenitor cells (LPCs) also take part in liver regeneration by acting as the origin of new hepatocytes when normal hepatocyte proliferation is severely impaired (Jiang et al., 2019a). Other signaling pathways such as nuclear receptors also play very important roles in liver enlargement and regeneration.

Nuclear receptors (NRs), a superfamily of ligand-activated transcription factors that convert different signals into the gene regulation (Mangelsdorf et al., 1995). Forty-eight types of NRs are now known in the human body and forty-nine types of NRs are found in mouse (Zhang et al., 2004; Helsen and Claessens, 2014). NRs consist of seven subfamilies (NR0-NR6) (Yang et al., 2020), the first six subfamilies were classified according to sequence homology in 1999 by Nuclear Nomenclature Committee, and the newly found NR subfamily with the one-conserved domain is categorized into subfamily 0 (Liu et al., 2017). There are typically five domains, which are named as $\mathrm{A} / \mathrm{B}, \mathrm{C}, \mathrm{D}, \mathrm{E}$, and $\mathrm{F}$ domain. The $\mathrm{A} / \mathrm{B}$ domain contains an amino-terminal ligand-dependent activation function domain. The $\mathrm{C}$ domain is a DNA -binding domain (DBD) containing two zinc fingers. D domain contains the nucleus localization sequence, which connects to the DBD with the $\mathrm{E}$ domain, which is also known as ligand binding domain (LBD). The function of $\mathrm{F}$ domain is still unclear (Vacca et al., 2013; Liu et al., 2017). The main function of NRs is xenobiotic sensing and detoxification (Yen, 2015), while they are also significant for cell growth, proliferation, differentiation, and metabolism and are associated with numerous liver 
diseases including nonalcoholic fatty liver disease, cholestatic liver disease, drug-induced liver disease (Rudraiah et al., 2016). Based on these findings, the structure, function of NRs and related liver diseases are summarized in Figure 1. Studies on NRs have provided better understanding of liver pathology and physiology, and some new strategies to treat liver diseases.

Mounting evidence have showed that some NRs are important regulator of hepatomegaly and liver regeneration. For example, pregnane $\mathrm{X}$ receptor (PXR), constitutive androstane receptor (CAR), peroxisome proliferators-activated receptors (PPARs), farnesoid X receptor (FXR), and liver X receptor (LXR) have been reported to be closely related to hepatomegaly and liver regeneration (Hall et al., 2012b; Rudraiah et al., 2016). Thus, this review aims to summarize the role of NRs in hepatomegaly and liver regeneration and the involved molecular mechanisms, and discuss future perspectives of NRs in the treatment of liver diseases. 


\section{NRs IN HEPATOMEGALY AND LIVER REGENERATIOAN}

In this section, we will review the roles of NRs such as PPARs, PXR, CAR, LXR and

FXR in hepatomegaly and liver regeneration and the molecular mechanisms involved.

The major agonists and antagonists of these NRs are summarized in Table 1.

\section{PPARs}

PPARs are transcription receptors that exert critical functions in regulating energy homeostasis and cell differentiation (Tontonoz and Spiegelman, 2008). PPARs consists of PPAR $\alpha$, PPAR $\beta / \delta$ and PPAR $\gamma$ (Vacca et al., 2013). Each of these isotypes shows unique physiological distribution and function in the tissues (Wang, 2010). PPAR $\alpha$ is mainly expressed in the liver, heart, kidney and intestine, which exerts critical functions in fatty acid uptake, $\beta$-oxidation, and lipid catabolism (Kersten and Stienstra, 2017). PPAR $\gamma$ is mainly expressed in adipose tissue and is involved in the regulation of adipogenesis, lipid storage, and glucose homeostasis. PPAR $\beta / \delta$ is widely expressed in liver, brain, kidney, heart and adipose tissue, which is associated with lipid catabolism, adipogenesis, wound cure as well as keratinocyte differentiation (Huang et al., 2009; Derosa et al., 2018; Mirza et al., 2019).

It has been reported that PPAR $\alpha$ activation by its agonists clofibrate and gemfibrozil can induce liver enlargement (Lenhard et al., 1999). Moreover, PPAR $\alpha$ is related to direct and compensatory hyperplasia by inducing the expressions of cell cycle-related genes (Morimura et al., 2006). In addition, activation of PPAR $\alpha$ by its agonist WY-14643 can induce the expression of c-Myc and miR-17-92 by inhibiting 
let-7c, which further promotes hepatocytes proliferation (Shah et al., 2007). Most recently, it's found that the activation of PPAR $\alpha$ by WY-14643 can induce hepatomegaly via yes-associated protein (YAP)-TEA domain family member (TEAD) signaling pathway by inducing hepatocytes hypertrophy around the central vein $(\mathrm{CV})$ area and promoting hepatocytes proliferation around the portal vein (PV) area in mice liver (Fan et al., 2021). Therefore, PPAR $\alpha$ is a potential modulator for hepatomegaly.

PPARs are also involved in the liver regeneration. PPAR $\alpha$ deficiency impairs the liver regeneration via altering the expression of the proliferation-related genes in mice (Anderson et al., 2002). Aldose reductase can accelerate the liver regeneration process by increasing the PPAR $\alpha$ and PPAR $\gamma$ expression in the aldose reductase-deficient mice liver (Li et al., 2020). Recent studies showed that hepatocyte PPAR $\alpha$ activation accelerates liver regeneration process after $\mathrm{PHx}$, which is associated with the regulation of cell cycle and lipid metabolism (Xie et al., 2019). PPAR $\alpha$ agonist WY-14643 was found to accelerate liver regeneration following PHx by interacting and activating YAP-TEAD signaling pathway (Fan et al., 2021).

The activation of PPAR $\gamma$ was reported to restrain the liver regeneration in rat, one of the mechanisms is that the activation of PPAR $\gamma$ can inhibit TNF $\alpha$ and IL- 6 which are important in the early stage of liver regeneration (Collino et al., 2010). The PPAR $\gamma$ agonist thiazolidinedione, rosiglitazone, can impair liver regeneration by inhibiting expression of cyclins in mice (Turmelle et al., 2006). Yu et al., reported that PPAR $\gamma$ transgenic mice showed hepatic steatosis and impaired liver regeneration post $\mathrm{PHx}$ (Yu et al., 2003). Furthermore, PPAR $\gamma$ can down-regulate cyclin D1, cyclin B1m, p27 
and up-regulate p38 mitogen activated protein kinase (MAPK), which suppresses the cell cycle in mice (Turmelle et al., 2006; Yamamoto et al., 2008). PPAR $\gamma$ activation exerts anti-inflammatory effects by inhibiting NF- $\mathrm{BB}$ and AP-1 transcription factors in hepatocytes and macrophages (Ogawa et al., 2005). So PPAR $\gamma$ is an important regulator in inflammation-induced liver regeneration and hepatomegaly. PPAR $\beta$ can modulate phosphoinositide-dependent kinase 1/AKT and E2f transcription factor signaling pathway, which is closely related to hepatocyte proliferation and liver regeneration in mice (Liu et al., 2013). Bezafibrate, a pan-agonists for all PPAR isotypes, suppresses the liver regeneration process after PHx in rat by inhibiting serine palmitoyltransferase, suggesting a negative effect of activation of PPARs on liver regeneration (Zabielski et al., 2010).

\section{PXR}

PXR, a ligand-activated transcription factor, is highly expressed in liver and gut (Kliewer et al., 1998). It usually interacts with retinoid $\mathrm{X}$ receptor $\alpha(\mathrm{RXR} \alpha)$ and exerts important functions in regulating the expression of drug-metabolizing enzymes and transporters which can affect drug disposition and drug-induced liver injury (Shehu AI, 2018). PXR is also involved in the progression of various liver diseases such as liver fibrosis and cholestatic liver disease (Cave et al., 2007; Wallace et al., 2010).

PXR plays a critical role in hepatocyte proliferation and liver size control. The murine PXR agonist, pregnenolone-16 $\alpha$-carbonitrile (PCN), can induce liver 
enlargement, which is abolished in Pxr-deficient mice (Garg et al., 1975; Staudinger et al., 2001). Zhou et al. firstly found that the activation of PXR can induce hepatomegaly with lipid accumulation in PXR -humanized mice by treating with rifampicin, which is a typical agonist of human PXR (Zhou et al., 2006). YAP is an important transcriptional coactivator in Hippo pathway and crucial in the control of organ size (Kowalik et al., 2011). It works as a transcriptional co-factor to participate in the organ size control by binding with TEAD or interaction with other transcription factors. It can also regulate liver size and liver regeneration by modulating hepatocyte proliferation and apoptosis (Patel et al., 2017). Pxr knockout mice undergoing PHx showed delayed liver regeneration and STAT3 inactivation was involved in the delayed regeneration process (Dai et al., 2008). Absence of PXR reduced hepatic fat accumulation accompanied by suppressed hepatocyte proliferation after PHx, suggesting that PXR-induced lipid accumulation is required for the hepatic regenerative response after PHx (Dai et al., 2008). Recent studies showed that PXR-induced hepatomegaly by PCN is YAP-dependent in mice, which is related to interact with YAP and promote nuclear YAP accumulation and then upregulation of YAP target genes (Jiang et al., 2019a). Schisandrol B, a PXR agonist, can induce hepatomegaly and promote liver regeneration in mice via activation of PXR and YAP (Zhao et al., 2021). Besides, schisandrol B can also promote liver regeneration after cholestatic liver injury in mice via increasing cyclin D1 and proliferating cell nuclear antigen expression while reducing p53 and p21 expression (Zeng et al., 2017). High-dose dexamethasone treatment can induce hepatomegaly and hepatocyte 
enlargement in mice by the activation of PXR and YAP signaling pathway and lipid accumulation (Jiao et al., 2020). Furthermore, a high dose of mifepristone, which is a synthetic antiprogesterone drug, can induce hepatomegaly in mice by activation of PXR, promoting PXR and YAP nuclear translocation, and then upregulating their downstream targets such as CYP3A11, CYP2B10, UGT1A1, ANKRD1, and CTGF (Yao et al., 2021). Additionally, PXR can elevate CAR- and PPAR $\alpha$-mediated, xenobiotic-induced hepatic proliferative response in mice (Shizu et al., 2013). Yoshinari et al. found that Imazalil can activate PXR to promote hepatocyte proliferation induced by CAR agonist 1,4-bis [2-(3,5-dichloropyridyloxy)] benzene (TCPOBOP) in mice liver (Shizu et al., 2018). PXR-promoted liver regeneration can be inhibited by forkhead box O3 (Shizu et al., 2016). DNA damage-inducible $45 \beta$ (GADD45 $\beta$ ) is a direct target of PXR (Kodama and Negishi, 2011), which facilitates hepatocyte survival by regulating c-Jun $\mathrm{N}$-terminal kinase pathway in the liver regeneration in mice (Papa et al., 2008).

\section{CAR}

CAR is an important intracellular xenobiotic sensor, which is mainly expressed in small intestine and liver (Xu et al., 2016). Like PXR, CAR regulates various genes encoding drug metabolizing enzymes such as CYP3A3 and CYP2B subfamily members, uridine 5'-diphosphate-glucuronosyltransferases, sulfotransferases and glutathione S-transferases (Gotoh et al., 2015). CAR is located in the cytoplasm by forming a complex with cytoplasmic CAR retention protein and heat shock protein 90 . 
Once activated, the complex is dissociated and CAR is translocated into the nucleus, where it can bind with $\operatorname{RXR} \alpha$, then the downstream target genes are activated (Kodama and Negishi, 2006). CAR plays a critical role in gluconeogenesis, lipid metabolism, hormone regulation, and hepatocyte proliferation. It is expressed at a higher level in the developing liver compared with the adult liver (Pascussi et al., 2007).

CAR also plays a vital role in hepatomegaly and liver regeneration. CAR activators, including phenobarbital and "barbital-like" compound TCPOBOP, can directly induce hepatomegaly (Costa et al., 2005), which is the consequence of hyperplasia and hypertrophy. Hepatocytes enlargement around CV area and hepatocytes proliferation around PV area were observed in TCPOBOP-treated mice (Gao et al., 2020). It has been reported that CAR activation can promote the $M d m 2$ gene expression to start the cell cycle and restrain apoptosis. (Huang et al., 2005; Gao et al., 2020). YAP-TEAD signaling pathway is also involved in CAR-mediated hepatomegaly. TCPOBOP-induced CAR activation promotes the translocation of YAP and elevates the expression of YAP-TEAD downstream targets, while CAR-dependent hepatocyte proliferation was milder in Yap knockout mice, suggesting that YAP is critical in CAR-promoted hepatomegaly (Abe et al., 2018; Gao et al., 2020). Verteporfin, a compound which can inhibit the interaction of YAP/TEAD, can relieve TCPOBOP-induced hepatomegaly in mice (Abe et al., 2018). Besides, c-Myc and forkhead box M1 gene are the key mediators of TCPOBOP-induced hepatomegaly (Blanco-Bose et al., 2008). FoxM1 represses phosphatase and tensin homologue 
(PTEN) and activates AKT signal pathway to promote liver growth (Yarushkin et al., 2019). Additionally, GADD45 $\beta$ has been reported to be related to the CAR-associated liver hypertrophy (Columbano et al., 2005). CAR can interact with GADD45 $\beta$ to suppress p38 MAPK signaling and promote hepatocyte proliferation in mice (Hori et al., 2018). A previous study showed that the lack of $\beta$-Catenin (CTNNB1) can suppress CAR activation-induced hepatocyte proliferation (Kodama and Negishi, 2006). Besides, TCPOBOP-induced proliferation is impeded by co-interruption of mesenchymal epithelial transition factor receptor (MET) and epidermal growth factor receptor signaling, even if CAR is activated (Bhushan et al., 2019).

As for liver regeneration, Car knockout mice displayed impaired capability of liver regeneration (Tschuor et al., 2016), while TCPOBOP can accelerate liver regeneration post $\mathrm{PHx}$ by promoting hepatocyte hypertrophy around the $\mathrm{CV}$ area and hepatocytes proliferation around the PV area in mice (Gao et al., 2020). The induction of CAR might be a possible therapeutic way to prevent small-for-size-syndrome (SFSS). It has been demonstrated that insufficient CAR induction can lead to liver failure after excessive tissue loss, reactivation of CAR by its agonist (6-(4-chlorophenyl) imidazo[2,1-b][1,3]thiazole-5-carbaldehydeO-(3,4-dichlorobenzyl)oxime) (CITCO), can promote the restoration of biochemical indicators related to liver injury after SFSS (Tschuor et al., 2016). So CAR is considered to be a primary mitogen to induce hepatocyte proliferation after PHx (Costa et al., 2005).

\section{LXR}


Up to now, there are two family members of LXR: LXR $\alpha$ and LXR $\beta$ (Peet et al., 1998). LXR $\alpha$ is mainly expressed in the liver, but LXR $\beta$ is relatively low in liver. LXR participates in modulating the expression of the genes which are involved in lipid and cholesterol homeostasis and plays critical role in membrane synthesis, cellular differentiation and proliferation (Lo Sasso et al., 2010a).

It has been reported that LXR is associated with hepatomegaly, but the mechanism involved remains unclear. Mice treated with LXR agonist T0901317 showed hepatomegaly, with a triglyceride accumulation (Jung et al., 2011). However, the LXR agonist T0901317 is also an agonist of PXR in vivo and in vitro, so the effect could have been mediated by PXR activation. The modulation of hepatomegaly and hepatocyte proliferation by T0901317 should be further studied to find out whether this effect is mediated by PXR activation or LXR $\alpha$ inhibition (Mitro et al., 2007; Zhang et al., 2020). Besides, LXR is inhibited in the liver regeneration process. After PHx, hepatocyte proliferation is induced accompanied by suppression of LXR in mice liver (Lo Sasso et al., 2010b). Inhibition of LXR-transcriptional pathways is crucial to ensure cholesterol levels of regenerating hepatocytes, and the activation of LXR by its agonist GW3965 can significantly reduce liver regeneration capacity during PHx (Lo Sasso et al., 2010b). Previous studies showed that hydroxysteroid sulfotransferase 2B1b can promote liver regeneration by inhibiting $\mathrm{LXR} \alpha$ activation in fatty liver and T0901317 treatment can attenuate the effect (Zhang et al., 2020). However, whether the inhibition of LXR causes liver regeneration is still questionable. 


\section{FXR}

There are two FXR family members: FXR $\alpha$ and FXR $\beta$. However, FXR $\beta$ is considered as a pseudogene in human (Otte et al., 2003). FXR is mainly expressed in the liver, kidney, intestine, and adrenal cortex (Parks et al., 1999). FXR is one of the main transcriptional regulators of bile acid homeostasis. It can interact with RXR to activate or inhibit FXR response element target genes by working with diverse co-activators, which participates in the modulation of cell cycle, apoptosis, and lipid metabolism (Modica et al., 2010).

Hepatomegaly is induced and ALT and ALP are increased in Fxr-null mice, which is related to elevated bile acid levels (Sinal et al., 2000; Kitada et al., 2003; Yang et al., 2007). However, long-term treatment of FXR agonist WAY-362450 can induce hepatomegaly in mice liver by activating cyclin D1 (Wu et al., 2019), and the mechanism of inducing hepatomegaly is different from Fxr-null mice. Although FXR is not necessary for liver growth induced by pregnancy, lack of FXR affect its normal mechanisms. In Fxr-deficient mice, hepatomegaly induced by pregnancy is carried out by the adaptive hepatocyte hyperplasia rather than hypertrophy (Milona et al., 2010).

FXR is also necessary in modulating liver regeneration. FXR plays a critical role in restoring the $\mathrm{CCl}_{4}$-injuried liver by disrupting hepatocyte death and inducing liver regeneration (Meng et al., 2010). Fxr knockout mice undergoing PHx showed elevated bile acid level, higher mortality, and delayed liver regeneration (Huang et al., 2006). Bile acid overloading can induce DNA oxidative damage, inflammation, cell 
over-proliferation in Fxr-deficient mice (Vacca et al., 2013). The activation of FXR mediated by liver injury or bile acid signaling after hepatectomy can induce liver regeneration via different mechanisms (Modica et al., 2010). The hepatic bile acid level tends to elevate after PHx under normal conditions. Increased bile acid can activate FXR to induce FoxM1b and c-Myc expression to protect hepatocytes from bile acid toxicity damage. Besides, it is also found that FXR alleviates the defects of age-related liver regeneration by induing the expression of Foxm1b with elevated DNA-duplication of hepatocytes (Chen et al., 2010).

It was confirmed that FXR activation can improve the liver metabolic ability, promote liver regeneration and inhibit cell death, which shows the therapeutic potential for FXR agonist for the prevention of liver failure during liver transplantation and resection (Vacca et al., 2013). It has been reported that the FXR agonist, obeticholic acid (OCA), can promote liver growth and liver regeneration during obstructive cholestasis. However, another study challenges the finding mentioned above because OCA treatment for rats cannot promote liver regeneration after cholestasis (de Haan et al., 2021). Some studies show that biliary epithelial cells (BEC) of zebrafish can transform into new hepatocytes by dedifferentiation into LPCs and then LPCs differentiated into hepatocytes, and BEC-derived cells proliferation also make contribution to the new hepatocytes formation (Choi et al., 2014). It has been reported that FXR activation in zebrafish can increase PTEN activity and inhibit PI3K-AKT-mammalian target of rapamycin pathway, which impedes BEC-driven liver regeneration, suggesting that targeting FXR for liver regeneration in clinic trial 
should be more personalized (Jung et al., 2020). Taken together, FXR is necessary in the modulation of liver repair and regeneration. 


\section{DISCUSSION AND PERSPECTIVES}

Hepatomegaly can be induced by numerous factors and divided into non-adverse hepatomegaly and adverse hepatomegaly (Wolf and Lavine, 2000). Liver regeneration is a critical process in liver repair post injuries, and it can be affected by many intrinsic and extrinsic factors (Forbes and Newsome, 2016). Liver regeneration after PHx is a process in which the residual liver tissue expands to function normally, and it is also known as compensatory hepatomegaly (Fausto et al., 2006). NRs take part in the regulation of cell growth and functions and are critical regulators of hepatocyte size and proliferation, and thus hepatomegaly and liver regeneration. The effects of NRs and their agonists on liver size and liver regeneration are listed in Table 2 and the major mechanisms for NR-mediated hepatomegaly and liver regeneration are summarized in Figure 2 and Table 3. NRs are critical in the modulation of inflammation, proliferation, lipid metabolism, and cell cycle, which plays a critical role in the liver regeneration and hepatomegaly progress. Thus, the NR transcriptome can serve as a therapeutic target for liver diseases that affects the proliferation of hepatocytes (Vacca et al., 2014). Regenerative process is involved in many liver diseases including cholestasis, fatty liver diseases, hepatic fibrosis and drug-induced liver injury, which indicates the universal potential of NRs for promoting liver repair in various hepatic diseases. Many NRs agonists have been widely used in clinic such as PXR agonist rifampicin, CAR agonist phenobarbital, PPAR $\alpha$ agonist fibrates and PPAR $\gamma$ agonist rosiglitazone. Future studies are required to assess their potential in promoting liver regeneration in clinic. 
YAP has been reported to be the common mechanism involved in PXR, CAR, or PPAR $\alpha$-induced hepatomegaly and live regeneration (Jiang et al., 2019a; Gao et al., 2020; Fan et al., 2021). The mechanisms of YAP signaling pathway mediating CAR-, PXR-, and PPAR $\alpha$-induced hepatomegaly and liver regeneration are depicted in Figure 3. Activation of PXR and PPAR $\alpha$ cannot induce liver enlargement in Yap knockout mice, suggesting that PXR or PPAR $\alpha$ activation-induced hepatomegaly is YAP-dependent. However, CAR activation-induced hepatomegaly is significantly suppressed but not totally abolished in Yap knockout mice. Other factors such as CTNNB1, c-Myc, and MET signaling are also involved in the hepatomegaly induced by CAR. Further studies are required to elucidate the diverse mechanisms of YAP in NR-induced liver enlargement. After activation of PXR, CAR, or PPAR $\alpha$ by their typical agonists, these NRs can interact with YAP and promote its nuclear translocation. E domain of PPAR $\alpha$ was identified to be essential for the interaction with YAP. Which domain of PXR or CAR is necessary for their interaction with YAP remains unclear but it has been included in our ongoing project. Further study is also required to measure the binding affinity between PXR, CAR, PPAR $\alpha$ and YAP and elucidate the binding sites specifically. Recent studies showed that YAP regulates gene transcription by forming liquid-liquid phase-separated bodies and engaging in super-enhancers (Franklin and Guan, 2020). It is interesting to determine the function of NRs in the regulation of YAP phase separation. Moreover, YAP is reported to be modulated by posttranslational modifications such as ubiquitination, phosphorylation, acetylation, methylation, sumoylation, and O-GlcNAcylation, which regulate its 
protein stability, transcriptional activity and subcellular localization at different stages (Yan et al., 2020). Whether PXR, CAR, or PPAR $\alpha$ regulates YAP activity via modulating its posttranslational modifications remained to be further studied.

YAP is required in the hepatocyte proliferation modulated by Myc which is also one of the transcriptional targets of YAP (Choi et al., 2018; Bisso et al., 2020). The overexpression of Myc can induce hepatocellular carcinomas, and Myc plays a key role in the PPAR $\alpha$ activation-induced liver cancer by upregulating the expression of mir-17-92 cluster and inducing the accelerated cell cycle progress and the defection of tumor cell apoptosis (Qu et al., 2014). The upregulation of the transcription of $c-M y c$ mRNA might be modulated by CAR through activating CTNNB1 and YAP signaling pathway (Shizu and Yoshinari, 2020). In addition, YAP is overactivated in various types of human cancers (Zender et al., 2006; Zhao et al., 2007; Steinhardt et al., 2008), and prolonged activation of YAP promotes cancer progression in mice (Moya and Halder, 2019), suggesting the potential risk of adverse side effects such as carcinogenesis. Besides, activation of CAR and PPAR $\alpha$ have clear mitogenic effect which is a typical factor to cause hepatomegaly and promote tumorigenesis at least in rodents (Locker, 2015; Yamada et al., 2021). Thus, the strategies to activate YAP by NRs agonists for regenerative therapy should be evaluated with caution.

Furthermore, crosstalk between nuclear receptors in the hepatomegaly was also reported, for example, PPAR $\alpha$ or CAR-induced hepatomegaly can be enhanced by PXR agonist (Shizu et al., 2013). GADD45 $\beta$, a transcriptional coactivator that facilitates rapid liver growth in mice, can be significantly induced by PXR or CAR 
activation and is associated with PXR or CAR-induced hepatic proliferative response.

The species difference of human and rodent NRs is also noted. The species difference of NRs between human and rodent, such as PXR and CAR, might be caused by the low homology of LBD (Yoshinari, 2019). For example, rodent CAR may interact with other hepatocyte proliferation-related proteins through the protein surface of LBD, while human CAR may not interact with these proteins (Shizu and Yoshinari, 2020). The transcriptional interactions of PXR and YAP have no clear species difference (Abe et al., 2019). Phenobarbital treatment of human primary hepatocytes in vitro doesn't cause hepatocyte proliferation and DNA duplication, but phenobarbital treatment can induce the hepatocyte proliferation in rat (Parzefall et al., 1991; Hirose et al., 2009; Soldatow et al., 2016; Okuda et al., 2017). Furthermore, the species difference in the CAR-mediated liver tumor formation may result from the protein-protein interaction between CAR and YAP, replicative DNA synthesis and hepatocyte proliferation (Yoshinari, 2019; Shizu and Yoshinari, 2020). The PY motif of the protein surface of mouse CAR interacts with the WW domain of YAP to activate YAP and induce hepatocyte proliferation, while the loss of PY motif results in the lack of the interaction in human liver (Shizu et al., 2020). It has been shown that PPAR $\alpha$-dependent rodent hepatocyte proliferation is absent in human liver, suggesting that PPAR $\alpha$-induced hepatomegaly is also species dependent (Gonzalez and Shah, 2008). PPAR $\alpha$ agonist WY-14643 or fenofibrate-induced liver enlargement in human and rodent is different, which might be related to distinct gene expression of PPAR $\alpha$ and peroxisome proliferation between humans and mice (Holden and Tugwood, 1999; 
Ye et al., 2003). The species difference might also be associated with the PPAR $\alpha$ target gene binding, the response to ligand activation, and the functional difference of PPAR $\alpha$ in mouse and human liver (Foreman et al., 2009). Thus, whether and how these NRs agonists can promote liver regeneration in human still need further investigations.

In summary, NRs exert critical effects on hepatomegaly and liver regeneration, which provides clinical relevance for promoting liver repair after liver injuries. Especially, NRs such as PXR, CAR or PPAR $\alpha$ can be potential targets to rescue SFSS during liver transplantation. Many clinically-used NRs' agonists also possess the potential to be used for promoting liver regeneration in clinic. 


\section{Author Contributions}

Participated in research design and revised the manuscript: $\mathrm{Bi}$ and Huang

Performed data analysis: Zhao, Fan and Gao

Wrote or contributed to the writing of the manuscript: Zhao, Fan and Gao 


\section{References}

Abe T, Amaike Y, Shizu R, Takahashi M, Kano M, Hosaka T, Sasaki T, Kodama S, Matsuzawa A, and Yoshinari K (2018) Role of YAP Activation in Nuclear Receptor CAR-Mediated Proliferation of Mouse Hepatocytes. Toxicol Sci 165:408-419.

Abe T, Shizu R, Sasaki T, Shimizu Y, Hosaka T, Kodama S, Matsuzawa A, and Yoshinari K (2019) Functional Interaction between Pregnane X Receptor and Yes-Associated Protein in Xenobiotic-Dependent Liver Hypertrophy and Drug Metabolism. J Pharmacol Exp Ther 371:590-601.

Almahmoud S, Elix CC, Jones JO, Hopkins CR, Vennerstrom JL, and Zhong HA (2021) Virtual screening and biological evaluation of PPAR $\gamma$ antagonists as potential anti-prostate cancer agents. Bioorganic \& Medicinal Chemistry 46: 116368.

Anderson SP, Yoon L, Richard EB, Dunn CS, Cattley RC, and Corton JC (2002) Delayed liver regeneration in peroxisome proliferator-activated receptor-alpha-null mice. Hepatology 36:544-554.

Bhushan B, Stoops JW, Mars WM, Orr A, Bowen WC, Paranjpe S, and Michalopoulos GK (2019) TCPOBOP-Induced Hepatomegaly and Hepatocyte Proliferation are Attenuated by Combined Disruption of MET and EGFR Signaling. Hepatology 69:1702-1718.

Bisso A, Filipuzzi M, Gamarra Figueroa GP, Brumana G, Biagioni F, Doni M, Ceccotti G, Tanaskovic N, Morelli MJ, Pendino V, Chiacchiera F, Pasini D, Olivero D, Campaner S, Sabò A, and Amati B (2020) Cooperation Between MYC and $\beta$-Catenin in Liver Tumorigenesis Requires Yap/Taz. Hepatology 72:1430-1443.

Blanco-Bose WE, Murphy MJ, Ehninger A, Offner S, Dubey C, Huang WD, Moore DD, and Trumpp A (2008) c-Myc and its target FoxM1 are critical downstream effectors of constitutive androstane receptor (CAR) mediated direct liver hyperplasia. Hepatology 48:1302-1311.

Cave M, Deaciuc I, Mendez C, Song ZY, Joshi-Barve S, Barve S, and McClain C (2007) Nonalcoholic fatty liver disease: predisposing factors and the role of nutrition. J Nutr Biochem 18:184-195.

Chai SC, Wright WC, and Chen T (2020) Strategies for developing pregnane $\mathrm{X}$ receptor antagonists: Implications from metabolism to cancer. Med Res Rev 40:1061-1083.

Chen WD, Wang YD, Zhang L, Shiah S, Wang M, Yang F, Yu D, Forman BM, and Huang W (2010) Farnesoid X receptor alleviates age-related proliferation defects in regenerating mouse livers by activating forkhead box m1b transcription. Hepatology 51:953-962.

Chen X, Song M, Chen W, Dimitrova-Shumkovska J, Zhao Y, Cao Y, Song Y, Yang W, Wang F, Xiang Y, and Yang C (2016) MicroRNA-21 Contributes to Liver Regeneration by Targeting PTEN. Med Sci Monit 22:83-91. 
Choi TY, Ninov N, Stainier DY, and Shin D (2014) Extensive conversion of hepatic biliary epithelial cells to hepatocytes after near total loss of hepatocytes in zebrafish. Gastroenterology 146:776-788.

Choi W, Kim J, Park J, Lee DH, Hwang D, Kim JH, Ashktorab H, Smoot D, Kim SY, Choi C, Koh GY, and Lim DS (2018) YAP/TAZ Initiates Gastric Tumorigenesis via Upregulation of MYC. Cancer Res 78:3306-3320.

Collino M, Aragno M, Castiglia S, Miglio G, Tomasinelli C, Boccuzzi G, Thiemermann C, and Fantozzi R (2010) Pioglitazone improves lipid and insulin levels in overweight rats on a high cholesterol and fructose diet by decreasing hepatic inflammation. Brit J Pharmacol 160:1892-1902.

Columbano A, Ledda-Columbano GM, Pibiri M, Cossu C, Menegazzi M, Moore DD, Huang W, Tian J, and Locker J (2005) Gadd45beta is induced through a CAR-dependent, TNF-independent pathway in murine liver hyperplasia. Hepatology 42:1118-1126.

Costa RH, Kalinichenko VV, Tan Y, and Wang IC (2005) The CAR nuclear receptor and hepatocyte proliferation. Hepatology 42:1004-1008.

Court FG, Wemyss-Holden SA, Dennison AR, and Maddern GJ (2002) The mystery of liver regeneration. British Journal of Surgery 89:1089-1095.

Dai GL, He L, Bu PL, and Wan YJY (2008) Pregnane X receptor is essential for normal progression of liver regeneration. Hepatology 47:1277-1287.

de Haan LR, Verheij J, van Golen RF, Horneffer-van der Sluis V, Lewis MR, Beuers UHW, van Gulik TM, Olde Damink SWM, Schaap FG, Heger M, and Olthof PB (2021) Unaltered Liver Regeneration in Post-Cholestatic Rats Treated with the FXR Agonist Obeticholic Acid. Biomolecules 11.

Derosa G, Sahebkar A, and Maffioli P (2018) The role of various peroxisome proliferator-activated receptors and their ligands in clinical practice. J Cell Physiol 233:153-161.

Fan S, Gao Y, Qu A, Jiang Y, Li H, Xie G, Yao X, Yang X, Zhu S, Yagai T, Tian J, Wang R, Gonzalez FJ, Huang M, and Bi H (2021) YAP-TEAD mediates peroxisome proliferator-activated receptor alpha-induced hepatomegaly and liver regeneration in mice. Hepatology.

Fausto N (2000) Liver regeneration. J Hepatol 32:19-31.

Fausto N, Campbell JS, and Riehle KJ (2006) Liver regeneration. Hepatology 43:S45-53.

Forbes SJ and Newsome PN (2016) Liver regeneration - mechanisms and models to clinical application. Nat Rev Gastroenterol Hepatol 13:473-485.

Foreman JE, Chang SC, Ehresman DJ, Butenhoff JL, Anderson CR, Palkar PS, Kang BH, Gonzalez FJ, and Peters JM (2009) Differential hepatic effects of perfluorobutyrate mediated by mouse and human PPAR-alpha. Toxicol Sci 110:204-211.

Franklin JM and Guan KL (2020) YAP/TAZ phase separation for transcription. Nat Cell Biol 22:357-358.

Gao Y, Fan S, Li H, Jiang Y, Yao X, Zhu S, Yang X, Wang R, Tian J, 
Gonzalez FJ, Huang M, and Bi H (2020) Constitutive androstane receptor induced-hepatomegaly and liver regeneration is partially via yes-associated protein activation. Acta Pharmaceutica Sinica $B$.

Garg BD, Kovacs K, Tuchweber B, and Khandekar JD (1975) Effect of pregnenolone-16alpha-carbonitrile, a microsomal enzyme inducer, on the regenerating rat liver. Acta Anat (Basel) 91:161-174.

Gonzalez FJ and Shah YM (2008) PPARalpha: mechanism of species differences and hepatocarcinogenesis of peroxisome proliferators. Toxicology 246:2-8.

Gotoh S, Ohno M, Yoshinari K, Negishi M, and Kawajiri K (2015) Nuclear Receptor-Mediated Regulation of Cytochrome P450 Genes, in: Cytochrome P450: Structure, Mechanism, and Biochemistry (Ortiz de Montellano PR ed), pp 787-812, Springer International Publishing, Cham.

Hall AP, Elcombe CR, Foster JR, Harada T, Kaufmann W, Knippel A, Kuttler K, Malarkey DE, Maronpot RR, Nishikawa A, Nolte T, Schulte A, Strauss V, and York MJ (2012a) Liver hypertrophy: a review of adaptive (adverse and non-adverse) changes--conclusions from the 3rd International ESTP Expert Workshop. Toxicol Pathol 40:971-994.

Hall AP, Elcombe CR, Foster JR, Harada T, Kaufmann W, Knippel A, Kuttler K, Malarkey DE, Maronpot RR, Nishikawa A, Nolte T, Schulte A, Strauss V, and York MJ (2012b) Liver Hypertrophy: A Review of Adaptive (Adverse and Non-adverse) Changes-Conclusions from the 3rd International ESTP Expert Workshop. Toxicologic Pathology 40:971-994.

Helder RWJ, Boiten WA, van Dijk R, Gooris GS, El Ghalbzouri A, and Bouwstra JA (2020) The effects of LXR agonist T0901317 and LXR antagonist GSK2033 on morphogenesis and lipid properties in full thickness skin models. Biochimica et Biophysica Acta (BBA) - Molecular and Cell Biology of Lipids 1865:158546.

Helsen C and Claessens F (2014) Looking at nuclear receptors from a new angle. Molecular and Cellular Endocrinology 382:97-106.

Higgins GM and Anderson RM (1931) Experimental pathology of the liver I Restoration of the liver of the white rat following partial surgical removal. Arch Pathol 12:186-202.

Hirose Y, Nagahori H, Yamada T, Deguchi Y, Tomigahara Y, Nishioka K, Uwagawa S, Kawamura S, Isobe N, Lake BG, and Okuno Y (2009) Comparison of the effects of the synthetic pyrethroid Metofluthrin and phenobarbital on CYP2B form induction and replicative DNA synthesis in cultured rat and human hepatocytes. Toxicology 258:64-69.

Holden PR and Tugwood JD (1999) Peroxisome proliferator-activated receptor alpha: role in rodent liver cancer and species differences. $J$ Mol Endocrinol 22:1-8.

Hori T, Saito K, Moore R, Flake GP, and Negishi M (2018) Nuclear Receptor CAR Suppresses GADD45B-p38 MAPK Signaling to Promote Phenobarbital-induced Proliferation in Mouse Liver. Mol Cancer Res 


\section{6:1309-1318.}

Huang TH, Teoh AW, Lin BL, Lin DS, and Roufogalis B (2009) The role of herbal PPAR modulators in the treatment of cardiometabolic syndrome. Pharmacol Res 60:195-206.

Huang W, Zhang J, Washington M, Liu J, Parant JM, Lozano G, and Moore DD (2005) Xenobiotic stress induces hepatomegaly and liver tumors via the nuclear receptor constitutive androstane receptor. Mol Endocrinol 19:1646-1653.

Huang WD, Ma K, Zhang J, Qatanani M, Cuvillier J, Liu J, Dong BN, Huang XF, and Moore DD (2006) Nuclear receptor-dependent bile acid signaling is required for normal liver regeneration. Science 312:233-236.

Jiang L, Zhang H, Xiao D, Wei H, and Chen Y (2021) Farnesoid X receptor (FXR): Structures and ligands. Computational and Structural Biotechnology Journal 19:2148-2159.

Jiang Y, Feng D, Ma X, Fan S, Gao Y, Fu K, Wang Y, Sun J, Yao X, Liu C, Zhang H, Xu L, Liu A, Gonzalez FJ, Yang Y, Gao B, Huang M, and Bi H (2019a) Pregnane X Receptor Regulates Liver Size and Liver Cell Fate by Yes-Associated Protein Activation in Mice. Hepatology 69:343-358.

Jiang YM, Feng DC, Ma XC, Fan SC, Gao Y, Fu KL, Wang Y, Sun JH, Yao XP, Liu CH, Zhang HZ, Xu LQ, Liu AM, Gonzalez FJ, Yang YZ, Gao B, Huang M, and Bi HC (2019b) Pregnane X Receptor Regulates Liver Size and Liver Cell Fate by Yes-Associated Protein Activation in Mice. Hepatology 69:343-358.

Jiao T, Yao X, Zhao Y, Zhou Y, Gao Y, Fan S, Chen P, Li X, Jiang Y, Yang X, Gonzalez FJ, Huang M, and Bi H (2020) Dexamethasone-Induced Liver Enlargement Is Related to PXR/YAP Activation and Lipid Accumulation but Not Hepatocyte Proliferation. Drug Metabolism and Disposition 48:830-839.

Jung K, Kim M, So J, Lee SH, Ko S, and Shin D (2020) Farnesoid X receptor activation impairs liver progenitor cell-mediated liver regeneration via the PTEN-PI3K-AKT-mTOR axis in zebrafish. Hepatology.

Jung UJ, Millman PN, Tall AR, and Deckelbaum RJ (2011) n-3 fatty acids ameliorate hepatic steatosis and dysfunction after LXR agonist ingestion in mice. Biochim Biophys Acta 1811:491-497.

Kaude JV and Deland F (1975) Hepatomegaly. Med Clin N Am 59:145-167.

Kersten S and Stienstra R (2017) The role and regulation of the peroxisome proliferator activated receptor alpha in human liver. Biochimie 136: $75-84$.

Kitada H, Miyata M, Nakamura T, Tozawa A, Honma W, Shimada M, Nagata K, Sinal CJ, Guo GL, Gonzalez FJ, and Yamazoe Y (2003) Protective role of hydroxysteroid sulfotransferase in lithocholic acid-induced liver toxicity. J Biol Chem 278:17838-17844.

Kliewer SA, Moore JT, Wade L, Staudinger JL, Watson MA, Jones SA, McKee DD, Oliver BB, Willson TM, Zetterstrom RH, Perlmann T, and 
Lehmann JM (1998) An orphan nuclear receptor activated by pregnanes defines a novel steroid signaling pathway. Cell 92:73-82.

Kodama S and Negishi M (2006) Phenobarbital confers its diverse effects by activating the orphan nuclear receptor car. Drug Metab Rev 38:75-87.

Kodama S and Negishi M (2011) Pregnane X receptor PXR activates the GADD45beta gene, eliciting the p38 MAPK signal and cell migration. $J$ Biol Chem 286:3570-3578.

Kowalik MA, Saliba C, Pibiri M, Perra A, Ledda-Columbano GM, Sarotto I, Ghiso E, Giordano S, and Columbano A (2011) Yes-Associated Protein Regulation of Adaptive Liver Enlargement and Hepatocellular Carcinoma Development in Mice. Hepatology 53:2086-2096.

Lenhard JM, Lancaster ME, Paulik MA, Weiel JE, Binz JG, Sundseth SS, Gaskill BA, Lightfoot RM, and Brown HR (1999) The RXR agonist LG100268 causes hepatomegaly, improves glycaemic control and decreases cardiovascular risk and cachexia in diabetic mice suffering from pancreatic beta-cell dysfunction. Diabetologia 42:545-554.

Li CX, Wang HW, Jiang WJ, Li GC, Zhang YD, Luo CH, and Li XC (2020) The Inhibition of Aldose Reductase Accelerates Liver Regeneration through Regulating Energy Metabolism. Oxid Med Cell Longev 2020.

Liu HX, Fang Y, Hu Y, Gonzalez FJ, Fang J, and Wan YJ (2013) PPARbeta Regulates Liver Regeneration by Modulating Akt and E2f Signaling. PLoS One 8:e65644.

Liu K, Zou C, and Qin B (2017) The association between nuclear receptors and ocular diseases. Oncotarget 8:27603-27615.

Lo Sasso G, Celli N, Caboni M, Murzilli S, Salvatore L, Morgano A, Vacca M, Pagliani T, Parini P, and Moschetta A (2010a) Down-Regulation of the LXR Transcriptome Provides the Requisite Cholesterol Levels to Proliferating Hepatocytes. Hepatology 51:1334-1344.

Lo Sasso G, Celli N, Caboni M, Murzilli S, Salvatore L, Morgano A, Vacca M, Pagliani T, Parini P, and Moschetta A (2010b) Down-regulation of the LXR transcriptome provides the requisite cholesterol levels to proliferating hepatocytes. Hepatology 51:1334-1344.

Locker J (2015) Chapter 14 - Mitogen-Induced Cell Proliferation and Cancer Promotion in the Liver, in: Liver Regeneration (Apte $\mathrm{U}$ ed), pp 199-212, Academic Press, Boston.

Mackowiak B, Li L, Lynch C, Ziman A, Heyward S, Xia M, and Wang H (2019) High-content analysis of constitutive androstane receptor (CAR) translocation identifies mosapride citrate as a CAR agonist that represses gluconeogenesis. Biochem Pharmacol 168:224-236.

Malato Y, Naqvi S, Schurmann N, Ng R, Wang B, Zape J, Kay MA, Grimm D, and Willenbring H (2011) Fate tracing of mature hepatocytes in mouse liver homeostasis and regeneration. J Clin Invest 121:4850-4860.

Mangelsdorf DJ, Thummel C, Beato M, Herrlich P, Schutz G, Umesono K, Blumberg B, Kastner P, Mark M, Chambon P, and Evans RM (1995) The 
nuclear receptor superfamily: the second decade. Cell 83:835-839.

Mani S, Dou W, and Redinbo MR (2013) PXR antagonists and implication in drug metabolism. Drug Metabolism Reviews 45:60-72.

Meng Z, Wang Y, Wang L, Jin W, Liu N, Pan H, Liu L, Wagman L, Forman BM, and Huang W (2010) FXR regulates liver repair after CCl4-induced toxic injury. Mol Endocrinol 24:886-897.

Michalopoulos GK (2017) Hepatostat: Liver regeneration and normal liver tissue maintenance. Hepatology 65:1384-1392.

Milona A, Owen BM, van Mil S, Dormann D, Mataki C, Boudjelal M, Cairns W, Schoonjans K, Milligan S, Parker M, White R, and Williamson C (2010) The normal mechanisms of pregnancy-induced liver growth are not maintained in mice lacking the bile acid sensor Fxr. Am J Physiol Gastrointest Liver Physiol 298:G151-158.

Minniti ME, Pedrelli M, Vedin LL, Delbes AS, Denis RGP, Oorni K, Sala C, Pirazzini C, Thiagarajan D, Nurmi HJ, Grompe M, Mills K, Garagnani P, Ellis ECS, Strom SC, Luquet SH, Wilson EM, Bial J, Steffensen KR, and Parini P (2020) Insights From Liver-Humanized Mice on Cholesterol Lipoprotein Metabolism and LXR-Agonist Pharmacodynamics in Humans. Hepatology 72:656-670.

Mirza AZ, Althagafi, II, and Shamshad H (2019) Role of PPAR receptor in different diseases and their ligands: Physiological importance and clinical implications. Eur J Med Chem 166:502-513.

Mitro N, Vargas L, Romeo R, Koder A, and Saez E (2007) T0901317 is a potent PXR ligand: implications for the biology ascribed to LXR. FEBS Lett 581:1721-1726.

Miyaoka Y, Ebato K, Kato H, Arakawa S, Shimizu S, and Miyajima A (2012) Hypertrophy and unconventional cell division of hepatocytes underlie liver regeneration. Curr Biol 22:1166-1175.

Modica S, Gadaleta RM, and Moschetta A (2010) Deciphering the nuclear bile acid receptor FXR paradigm. Nucl Recept Signal 8:e005.

Morimura K, Cheung C, Ward JM, Reddy JK, and Gonzalez FJ (2006) Differential susceptibility of mice humanized for peroxisome proliferator-activated receptor alpha to Wy-14,643-induced liver tumorigenesis. Carcinogenesis 27:1074-1080.

Moya IM and Halder G (2019) Hippo-YAP/TAZ signalling in organ regeneration and regenerative medicine. Nat Rev Mol Cell Biol 20:211-226.

Ogawa S, Lozach J, Benner C, Pascual G, Tangirala RK, Westin S, Hoffmann A, Subramaniam S, David M, Rosenfeld MG, and Glass CK (2005) Molecular determinants of crosstalk between nuclear receptors and toll-like receptors. Cell 122:707-721.

Okuda Y, Kushida M, Kikumoto H, Nakamura Y, Higuchi H, Kawamura S, Cohen SM, Lake BG, and Yamada T (2017) Evaluation of the human relevance of the constitutive androstane receptor-mediated mode of action for rat hepatocellular tumor formation by the synthetic pyrethroid momfluorothrin. 


\section{J Toxicol Sci 42:773-788.}

Otte K, Kranz H, Kober I, Thompson P, Hoefer M, Haubold B, Remmel B, Voss H, Kaiser C, Albers M, Cheruvallath Z, Jackson D, Casari G, Koegl M, Paabo S, Mous J, Kremoser C, and Deuschle U (2003) Identification of farnesoid $\mathrm{X}$ receptor beta as a novel mammalian nuclear receptor sensing lanosterol. Molecular and Cellular Biology 23:864-872.

Papa S, Zazzeroni F, Fu YX, Bubici C, Alvarez K, Dean K, Christiansen PA, Anders RA, and Franzoso G (2008) Gadd45beta promotes hepatocyte survival during liver regeneration in mice by modulating JNK signaling. $J$ Clin Invest 118:1911-1923.

Parks DJ, Blanchard SG, Bledsoe RK, Chandra G, Consler TG, Kliewer SA, Stimmel JB, Willson TM, Zavacki AM, Moore DD, and Lehmann JM (1999) Bile acids: natural ligands for an orphan nuclear receptor. Science 284:1365-1368.

Parzefall W, Erber E, Sedivy R, and Schulte-Hermann R (1991) Testing for induction of DNA synthesis in human hepatocyte primary cultures by rat liver tumor promoters. Cancer Res 51:1143-1147.

Pascussi JM, Robert A, Moreau A, Ramos J, Bioulac-Sage P, Navarro F, Blanc P, Assenat E, Maurel P, and Vilarem MJ (2007) Differential regulation of constitutive androstane receptor expression by hepatocyte nuclear factor4alpha isoforms. Hepatology 45:1146-1153.

Patel SH, Camargo FD, and Yimlamai D (2017) Hippo Signaling in the Liver Regulates Organ Size, Cell Fate, and Carcinogenesis. Gastroenterology 152:533-545.

Peet DJ, Janowski BA, and Mangelsdorf DJ (1998) The LXRs: a new class of oxysterol receptors. Curr Opin Genet Dev 8:571-575.

Qu A, Jiang C, Cai Y, Kim JH, Tanaka N, Ward JM, Shah YM, and Gonzalez FJ (2014) Role of Myc in hepatocellular proliferation and hepatocarcinogenesis. J Hepatol 60:331-338.

Ross J, Plummer SM, Rode A, Scheer N, Bower CC, Vogel O, Henderson CJ, Wolf CR, and Elcombe CR (2010) Human Constitutive Androstane Receptor (CAR) and Pregnane X Receptor (PXR) Support the Hypertrophic but not the Hyperplastic Response to the Murine Nongenotoxic Hepatocarcinogens Phenobarbital and Chlordane In Vivo. Toxicol Sci 116:452-466.

Rudraiah S, Zhang X, and Wang L (2016) Nuclear Receptors as Therapeutic Targets in Liver Disease: Are We There Yet? Annu Rev Pharmacol 56:605-626.

Shah YM, Morimura K, Yang Q, Tanabe T, Takagi M, and Gonzalez FJ (2007) Peroxisome proliferator-activated receptor alpha regulates a microRNA-mediated signaling cascade responsible for hepatocellular proliferation. Mol Cell Biol 27:4238-4247.

Shehu AI MX (2018) Pregnane X receptor in drug-induced liver injury: friend or foe? Liver Research 2:173-179. 
Shizu R, Abe T, Benoki S, Takahashi M, Kodama S, Miayata M, Matsuzawa A, and Yoshinari K (2016) PXR stimulates growth factor-mediated hepatocyte proliferation by cross-talk with the FOXO transcription factor. Biochem J 473:257-266.

Shizu R, Abe T, Sobe K, Ishimura M, Hosaka T, Sasaki T, and Yoshinari $\mathrm{K}$ (2020) A7 - Interaction with yap is a possible underlying mechanism for car-dependent hepatocarcinogenesis. Drug Metabolism and Pharmacokinetics 35:S20.

Shizu R, Benoki S, Numakura Y, Kodama S, Miyata M, Yamazoe Y, and Yoshinari K (2013) Xenobiotic-induced hepatocyte proliferation associated with constitutive active/androstane receptor (CAR) or peroxisome proliferator-activated receptor alpha (PPARalpha) is enhanced by pregnane $\mathrm{X}$ receptor (PXR) activation in mice. PLoS One 8:e61802.

Shizu R, Kano M, Abe T, Tsuchiya S, Shimizu Y, Watanabe M, Hosaka T, Sasaki T, and Yoshinari K (2018) Screening of Industrial and Agricultural Chemicals for Searching a Mouse PXR Activator Using Cell-Based Reporter Gene Assays. BPB Reports 1:11-19.

Shizu R and Yoshinari K (2020) Nuclear receptor CAR-mediated liver cancer and its species differences. Expert Opin Drug Metab Toxicol 16:343-351.

Sinal CJ, Tohkin M, Miyata M, Ward JM, Lambert G, and Gonzalez FJ (2000) Targeted disruption of the nuclear receptor FXR/BAR impairs bile acid and lipid homeostasis. Cell 102:731-744.

Soldatow V, Peffer RC, Trask OJ, Cowie DE, Andersen ME, LeCluyse E, and Deisenroth C (2016) Development of an in vitro high content imaging assay for quantitative assessment of CAR-dependent mouse, rat, and human primary hepatocyte proliferation. Toxicol In Vitro 36:224-237.

Staudinger J, Liu Y, Madan A, Habeebu S, and Klaassen CD (2001) Coordinate regulation of xenobiotic and bile acid homeostasis by pregnane $\mathrm{X}$ receptor. Drug Metab Dispos 29:1467-1472.

Stebbins KJ, Broadhead AR, Cabrera G, Correa LD, Messmer D, Bundey R, Baccei C, Bravo Y, Chen A, Stock NS, Prasit P, and Lorrain DS (2017) In vitro and in vivo pharmacology of NXT629, a novel and selective PPAR $\alpha$ antagonist. European Journal of Pharmacology 809:130-140.

Steinhardt AA, Gayyed MF, Klein AP, Dong J, Maitra A, Pan D, Montgomery EA, and Anders RA (2008) Expression of Yes-associated protein in common solid tumors. Hum Pathol 39:1582-1589.

Taub R (2004) Liver regeneration: From myth to mechanism. Nat Rev Mol Cell Bio 5:836-847.

Tontonoz P and Spiegelman BM (2008) Fat and beyond: The diverse biology of PPAR gamma. Annu Rev Biochem 77:289-312.

Tschuor C, Kachaylo E, Limani P, Raptis DA, Linecker M, Tian Y, Herrmann U, Grabliauskaite K, Weber A, Columbano A, Graf R, Humar B, and Clavien PA (2016) Constitutive androstane receptor (Car)-driven 
regeneration protects liver from failure following tissue loss. J Hepatol 65:66-74.

Turmelle YP, Shikapwashya O, Tu S, Hruz PW, Yan Q, and Rudnick DA (2006) Rosiglitazone inhibits mouse liver regeneration. Faseb $J$ 20:2609-2611.

Vacca M, D'Amore S, Graziano G, D'Orazio A, Cariello M, Massafra V, Salvatore L, Martelli N, Murzilli S, Lo Sasso G, Mariani-Costantini R, and Moschetta A (2014) Clustering Nuclear Receptors in Liver Regeneration Identifies Candidate Modulators of Hepatocyte Proliferation and Hepatocarcinoma. Plos One 9.

Vacca M, Degirolamo C, Massafra V, Polimeno L, Mariani-Costantini R, Palasciano G, and Moschetta A (2013) Nuclear receptors in regenerating liver and hepatocellular carcinoma. Mol Cell Endocrinol 368:108-119.

Wallace K, Cowie DE, Konstantinou DK, Hill SJ, Tjelle TE, Axon A, Koruth M, White SA, Carlsen H, Mann DA, and Wright MC (2010) The PXR is a drug target for chronic inflammatory liver disease. J Steroid Biochem 120: $137-148$.

Wang YX (2010) PPARs: diverse regulators in energy metabolism and metabolic diseases. Cell Res 20:124-137.

Willson TM, Brown PJ, Sternbach DD, and Henke BR (2000) The PPARs: From Orphan Receptors to Drug Discovery. Journal of Medicinal Chemistry 43:527-550.

Wolf AD and Lavine JE (2000) Hepatomegaly in neonates and children. Pediatr Rev 21:303-310.

Wu W, Wu Q, and Liu X (2019) Chronic activation of FXR-induced liver growth with tissue-specific targeting Cyclin D1. Cell Cycle 18:1784-1797.

Xie G, Yin S, Zhang Z, Qi D, Wang X, Kim D, Yagai T, Brocker CN, Wang Y, Gonzalez FJ, Wang H, and Qu A (2019) Hepatocyte Peroxisome Proliferator-Activated Receptor alpha Enhances Liver Regeneration after Partial Hepatectomy in Mice. Am J Pathol 189:272-282.

Xu C, Huang M, and Bi H (2016) PXR- and CAR-mediated herbal effect on human diseases. Biochim Biophys Acta 1859:1121-1129.

Yamada T, Cohen SM, and Lake BG (2021) Critical evaluation of the human relevance of the mode of action for rodent liver tumor formation by activators of the constitutive androstane receptor (CAR). Crit Rev Toxicol 51:373-394.

Yamamoto Y, Ono T, Dhar DK, Yamanoi A, Tachibana M, Tanaka T, and Nagasue N (2008) Role of peroxisome proliferator-activated receptor-gamma (PPARgamma) during liver regeneration in rats. J Gastroenterol Hepatol 23:930-937.

Yan F, Qian M, He Q, Zhu H, and Yang B (2020) The posttranslational modifications of Hippo-YAP pathway in cancer. Biochim Biophys Acta Gen Subj 1864:129397.

Yang F, Huang X, Yi T, Yen Y, Moore DD, and Huang W (2007) 
Spontaneous development of liver tumors in the absence of the bile acid receptor farnesoid X receptor. Cancer Res 67:863-867.

Yang X, Gonzalez FJ, Huang M, and Bi H (2020) Nuclear receptors and non-alcoholic fatty liver disease: An update. Liver Research 4:88-93.

Yao XP, Jiao TY, Jiang YM, Fan SC, Zhao YY, Yang X, Gao Y, Li F, Zhou YY, Chen PP, Huang M, and Bi HC (2021) PXR mediates mifepristone-induced hepatomegaly in mice. Acta Pharmacol Sin.

Yarushkin AA, Mazin ME, Pustylnyak YA, Prokopyeva EA, and Pustylnyak VO (2019) Promotion of liver growth by CAR is accompanied by Akt pathway activation and FoxM1-Nedd4-mediated repression of PTEN. Arch Biochem Biophys 672:108065.

Ye JM, Iglesias MA, Watson DG, Ellis B, Wood L, Jensen PB, Sorensen RV, Larsen PJ, Cooney GJ, Wassermann K, and Kraegen EW (2003) PPARalpha /gamma ragaglitazar eliminates fatty liver and enhances insulin action in fat-fed rats in the absence of hepatomegaly. Am J Physiol Endocrinol Metab 284:E531-540.

Yen PM (2015) Classical nuclear hormone receptor activity as a mediator of complex biological responses: A look at health and disease. Best Pract Res Cl En 29:517-528.

Yoshinari K (2019) Role of Nuclear Receptors PXR and CAR in Xenobiotic-Induced Hepatocyte Proliferation and Chemical Carcinogenesis. Biol Pharm Bull 42:1243-1252.

Yu S, Matsusue K, Kashireddy P, Cao WQ, Yeldandi V, Yeldandi AV, Rao MS, Gonzalez FJ, and Reddy JK (2003) Adipocyte-specific gene expression and adipogenic steatosis in the mouse liver due to peroxisome proliferator-activated receptor gamma1 (PPARgamma1) overexpression. $J$ Biol Chem 278:498-505.

Zabielski P, Blachnio-Zabielska A, Baranowski M, Zendzian-Piotrowska M, and Gorski J (2010) Activation of PPAR alpha by bezafibrate negatively affects de novo synthesis of sphingolipids in regenerating rat liver. Prostag Oth Lipid M 93:120-125.

Zender L, Spector MS, Xue W, Flemming P, Cordon-Cardo C, Silke J, Fan ST, Luk JM, Wigler M, Hannon GJ, Mu D, Lucito R, Powers S, and Lowe SW (2006) Identification and validation of oncogenes in liver cancer using an integrative oncogenomic approach. Cell 125:1253-1267.

Zeng H, Jiang Y, Chen P, Fan X, Li D, Liu A, Ma X, Xie W, Liu P, Gonzalez FJ, Huang M, and Bi H (2017) Schisandrol B protects against cholestatic liver injury through pregnane $\mathrm{X}$ receptors. $\mathrm{Br} J$ Pharmacol 174:672-688.

Zhang X, Xu YY, Bai QM, Li XB, Han J, Hou YY, Ji Y, and Zhang ZG (2020) Inhibition of LXR signaling by SULT2B1b promotes liver regeneration after partial hepatectomy in mouse models of nonalcoholic fatty liver disease. Am J Physiol-Gastr L 319:G87-G96.

Zhang Z, Burch PE, Cooney AJ, Lanz RB, Pereira FA, Wu J, Gibbs RA, 
Weinstock G, and Wheeler DA (2004) Genomic analysis of the nuclear receptor family: new insights into structure, regulation, and evolution from the rat genome. Genome Res 14:580-590.

Zhao B, Wei X, Li W, Udan RS, Yang Q, Kim J, Xie J, Ikenoue T, Yu J, Li L, Zheng P, Ye K, Chinnaiyan A, Halder G, Lai ZC, and Guan KL (2007) Inactivation of YAP oncoprotein by the Hippo pathway is involved in cell contact inhibition and tissue growth control. Genes Dev 21:2747-2761.

Zhao YY, Yao XP, Jiao TY, Tian JN, Gao Y, Fan SC, Chen PP, Jiang YM, Zhou YY, Chen YX, Yang X, Huang M, and Bi HC (2021) Schisandrol B promotes liver enlargement via activation of PXR and YAP pathways in mice. Phytomedicine 84:153520.

Zhou J, Zhai Y, Mu Y, Gong H, Uppal H, Toma D, Ren S, Evans RM, and Xie W (2006) A novel pregnane $X$ receptor-mediated and sterol regulatory element-binding protein-independent lipogenic pathway. $J$ Biol Chem 281:15013-15020. 
Footnotes:

\section{Funding footnote}

The work was supported by the Natural Science Foundation of China (Grants: 82025034, 81973392); the National Key Research and Development Program (Grant: 2017YFE0109900); the Shenzhen Science and Technology Program (No. KQTD20190929174023858); the Natural Science Foundation of Guangdong (Grant: 2017A030311018); the 111 project (Grant: B16047); the Key Laboratory Foundation of Guangdong Province (Grant: 2017B030314030); the Local Innovative and Research Teams Project of Guangdong Pearl River Talents Program (2017BT01Y093); and the National Engineering and Technology Research Center for New drug Druggability Evaluation (Seed Program of Guangdong Province, 2017B090903004).

\section{Financial Disclosure and Conflict of Interest:}

The authors have no financial disclosures, and no conflicts of interest with the contents of this article. 


\section{Legends for Figures}

Figure 1. The structure, function of NRs and related liver diseases.

Figure 2. Mechanisms involved in NR-mediated hepatomegaly (A) and liver regeneration $(\mathrm{B})$.

Figure 3. YAP signaling pathway mediates CAR-, PXR- or PPAR $\alpha$-induced hepatomegaly and liver regeneration. 
Table 1. Major agonists and antagonists of NRs

\begin{tabular}{|c|c|c|c|}
\hline Target & Agonist/Antagonist & Drug/Compound & Reference(s) \\
\hline \multirow{13}{*}{ PXR } & \multirow{6}{*}{ Agonist } & $\mathrm{PCN}$ & Jiang et al., 2019 \\
\hline & & Rifampicin & Jiang et al., 2019 \\
\hline & & Imazalil & Shizu et al., 2018 \\
\hline & & Dexamethasone & Jiao et al., 2020 \\
\hline & & Schisandrol B & Zhao et al., 2021 \\
\hline & & Mifepristone & Yao et al., 2021 \\
\hline & \multirow{7}{*}{ Antagonist } & ET-743 & Chai et al., 2020 \\
\hline & & Polychlorinated & Mani et al., 2013 \\
\hline & & biphenyls & Mani et al., 2013 \\
\hline & & Fluconazole & Mani et al., 2013 \\
\hline & & Enilconazole & Mani et al., 2013 \\
\hline & & Sesamin & Mani et al., 2013 \\
\hline & & Metformin & Mani et al., 2013 \\
\hline \multirow{7}{*}{$\operatorname{PPAR} \alpha$} & \multirow{4}{*}{ Agonist } & Clofibrate & Lenhard et al., 1999 \\
\hline & & WY-14643 & Fan et al., 2021 \\
\hline & & Gemfibrozil & Lenhard et al., 1999 \\
\hline & & Fenofibrate & Willson et al., 2000 \\
\hline & \multirow{3}{*}{ Antagonist } & GW6471 & Stebbins et al., 2017 \\
\hline & & MK886 & Stebbins et al., 2017 \\
\hline & & NXT629 & Stebbins et al., 2017 \\
\hline \multirow{4}{*}{ PPAR $\gamma$} & \multirow{2}{*}{ Agonist } & Rosiglitazone & Turmelle et al., 2006 \\
\hline & & Pioglitazone & Collino et al., 2010 \\
\hline & \multirow{2}{*}{ Antagonist } & GW9662 & Almahmoud et al., 2021 \\
\hline & & T0070907 & Almahmoud et al., 2021 \\
\hline \multirow{5}{*}{ CAR } & \multirow{3}{*}{ Agonist } & CITCO & Tschuor et al., 2016 \\
\hline & & Phenobarbital & Huang et al., 2005 \\
\hline & & TCPOBOP & Gao et al., 2020 \\
\hline & \multirow{2}{*}{ Antagonist } & PK11195 & Mackowiak et al., 2019 \\
\hline & & CINPA1 & Mackowiak et al., 2019 \\
\hline \multirow{3}{*}{ LXR } & \multirow{2}{*}{ Agonist } & T0901317 & Jung et al., 2011 \\
\hline & & GW3965 & Minniti et al., 2020 \\
\hline & Antagonist & GSK2033 & Helder et al., 2020 \\
\hline \multirow{4}{*}{ FXR } & \multirow{2}{*}{ Agonist } & WAY-362450 & Wu et al., 2019 \\
\hline & & OCA & de Haan et al., 2021 \\
\hline & \multirow{2}{*}{ Antagonist } & DY268 & Jiang et al., 2021 \\
\hline & & FLG249 & Jiang et al., 2021 \\
\hline
\end{tabular}




\begin{tabular}{|c|c|c|c|}
\hline NRs & Activators or agonists & Effects on liver size and regeneration & Reference(s) \\
\hline PXR & $\mathrm{PCN}$ & $\begin{array}{c}\text { Induces liver enlargement and liver regeneration via activation } \\
\text { of YAP signaling pathway }\end{array}$ & Jiang et al., 2019 \\
\hline PXR & Rifampicin & $\begin{array}{c}\text { Induces liver enlargement and liver regeneration via activation } \\
\text { of YAP signaling pathway }\end{array}$ & Jiang et al., 2019 \\
\hline PXR & Imazalil & $\begin{array}{l}\text { Activates PXR to elevate hepatocyte proliferation induced by } \\
\text { CAR }\end{array}$ & Shizu et al., 2018 \\
\hline PXR & Dexamethasone & $\begin{array}{c}\text { Induces hepatomegaly by the activation of YAP signaling } \\
\text { pathway and lipid accumulation }\end{array}$ & Jiao et al., 2020 \\
\hline PXR & Schisandrol B & $\begin{array}{l}\text { Induces hepatomegaly and hepatocyte proliferation by } \\
\text { activation of YAP signaling pathway }\end{array}$ & Zhao et al., 2021 \\
\hline PXR & Mifepristone & $\begin{array}{l}\text { Induces hepatomegaly by promoting PXR and YAP nuclear } \\
\text { translocation }\end{array}$ & Yao et al., 2021 \\
\hline PPAR $\alpha$ & Clofibrate & Induces liver enlargement & Lenhard et al., 1999 \\
\hline PPAR $\alpha$ & WY-14643 & $\begin{array}{l}\text { Promotes liver enlargement and liver regeneration via activation } \\
\text { of YAP-TEAD signaling pathway }\end{array}$ & Fan et al., 2021 \\
\hline PPAR $\alpha$ & Gemfibrozil & Induces liver enlargement & Lenhard et al., 1999 \\
\hline PPAR $\gamma$ & Rosiglitazone & $\begin{array}{l}\text { Impairs liver regeneration process by down-regulation of cyclin } \\
\text { expression }\end{array}$ & Turmelle et al., 2006 \\
\hline CAR & CITCO & Promotes hepatomegaly and liver regeneration in SFSS model & Tschuor et al., 2016 \\
\hline CAR & Phenobarbital & Induces hepatomegaly by activating $M d m 2$ gene expression & Huang et al., 2005 \\
\hline
\end{tabular}




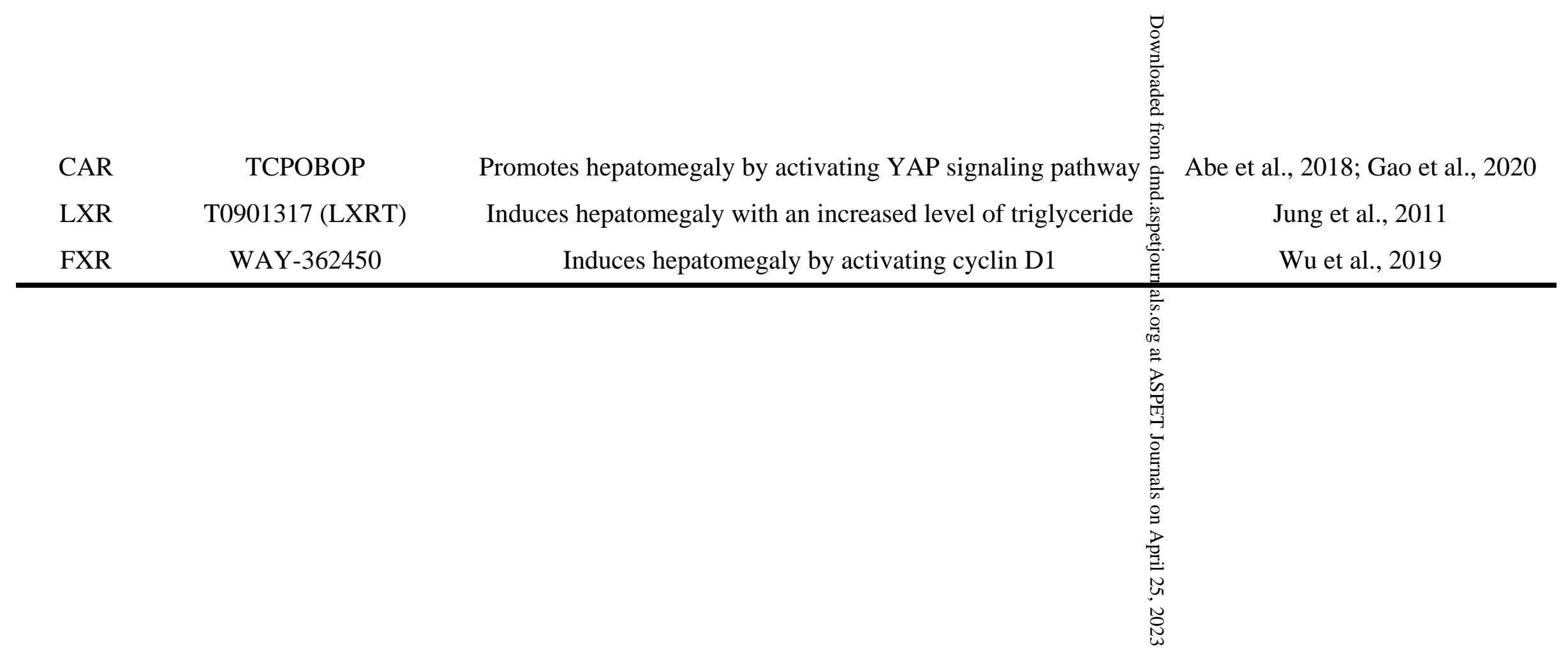




\begin{tabular}{|c|c|c|c|}
\hline NRs & Effects & Mechanisms & Reference(s) \\
\hline PXR & Hepatomegaly $\uparrow$ & Induces hyperplasia and hypertrophy by YAP signaling pathway & Jiang et al., 2019 \\
\hline PXR & $\begin{array}{l}\text { Liver } \\
\text { regeneration } \uparrow\end{array}$ & Accelerates liver regeneration by YAP signaling pathway & $\begin{array}{l}\text { Yoshinari, 2019; Jiang et } \\
\text { al., } 2019\end{array}$ \\
\hline PPAR $\alpha$ & Hepatomegaly $\uparrow$ & $\begin{array}{l}\text { 1. Induces gene expression of Ras, Rho } \alpha \text { and } c-M y c \text { oncogene expression } \\
\text { which are important for hepatocyte proliferation and hep } \\
\text { hyperplasia; } \\
\text { 2. Interacts with YAP-TEAD signaling pathway }\end{array}$ & $\begin{array}{l}\text { Morimura et al., 2006, Shah } \\
\text { et al., 2007; Fan et al., } 2021\end{array}$ \\
\hline PPAR $\alpha$ & $\begin{array}{l}\text { Liver } \\
\text { regeneration } \uparrow\end{array}$ & $\begin{array}{l}\text { 1. Interacts with YAP-TEAD signaling pathway and induce liver } \\
\text { regeneration } \\
\text { 2. Regulates cell cycle and lipid homeostasis }\end{array}$ & $\begin{array}{l}\text { Fan et al., 2021; Xie et al., } \\
2019\end{array}$ \\
\hline PPAR $\gamma$ & $\begin{array}{l}\text { Liver } \\
\text { regeneration } \downarrow\end{array}$ & $\begin{array}{l}\text { Reduces TNF } \alpha \text { and IL- } 6 \text { in the liver which are important in the early phase } \\
\text { of liver regeneration }\end{array}$ & Collino et al., 2010 \\
\hline CAR & Hepatomegaly $\uparrow$ & $\begin{array}{l}\text { 1. Activates the expression of the } M d m 2 \text { gene to start the cell cycle and } \\
\text { restrain apoptosis; } \\
\text { 2. YAP can regulate the expression of proliferation genes such as } c-M y c \\
\text { and FoxM1 } \\
\text { 3. GADD } 45 \beta \text { has been reported to be related to the CAR-associated liver } \\
\text { hypertrophy }\end{array}$ & $\begin{array}{l}\text { Huang et al., 2005, Costa et } \\
\text { al., 2003, Hori et al., 2018; } \\
\text { Gao et al., } 2020\end{array}$ \\
\hline
\end{tabular}


4. Interacts with YAP-TEAD signaling pathway

\begin{tabular}{|c|c|c|c|}
\hline CAR & $\begin{array}{l}\text { Liver } \\
\text { regeneration } \uparrow\end{array}$ & $\begin{array}{l}\text { YAP activation induced by CAR can regulate the expression } \begin{array}{l}\text { क्. } \\
\text { proliferation-related genes such as c-Myc and FoxM1 }\end{array} \\
\text { pox }\end{array}$ & $\begin{array}{l}\text { Costa et al., 2003; Gao et } \\
\text { al., } 2020\end{array}$ \\
\hline LXR & Hepatomegaly & Not clear & - \\
\hline LXR & $\begin{array}{l}\text { Liver } \\
\text { regeneration } \downarrow\end{array}$ & $\begin{array}{l}\text { LXR activation can reduce liver regeneration capacity by regulati } \\
\text { cholesterol metabolism }\end{array}$ & Calkin and Tontonoz, 2010 \\
\hline FXR & Hepatomegaly & $\begin{array}{l}\text { 1. Fxr-null mice showed increased bile acid level and hepatomegaly } \\
\text { 2. Chronic activation by WAY-362450 induces hepatomegaly by activat } \\
\text { cyclin D1 }\end{array}$ & $\begin{array}{l}\text { Wu et al., 2019; Yang et al., } \\
2007\end{array}$ \\
\hline FXR & $\begin{array}{c}\text { Liver } \\
\text { regeneration } \uparrow\end{array}$ & Induces the expression of Foxm $1 b$ and $c-M y c$ & de Haan et al., 2021 \\
\hline
\end{tabular}


Figure 1

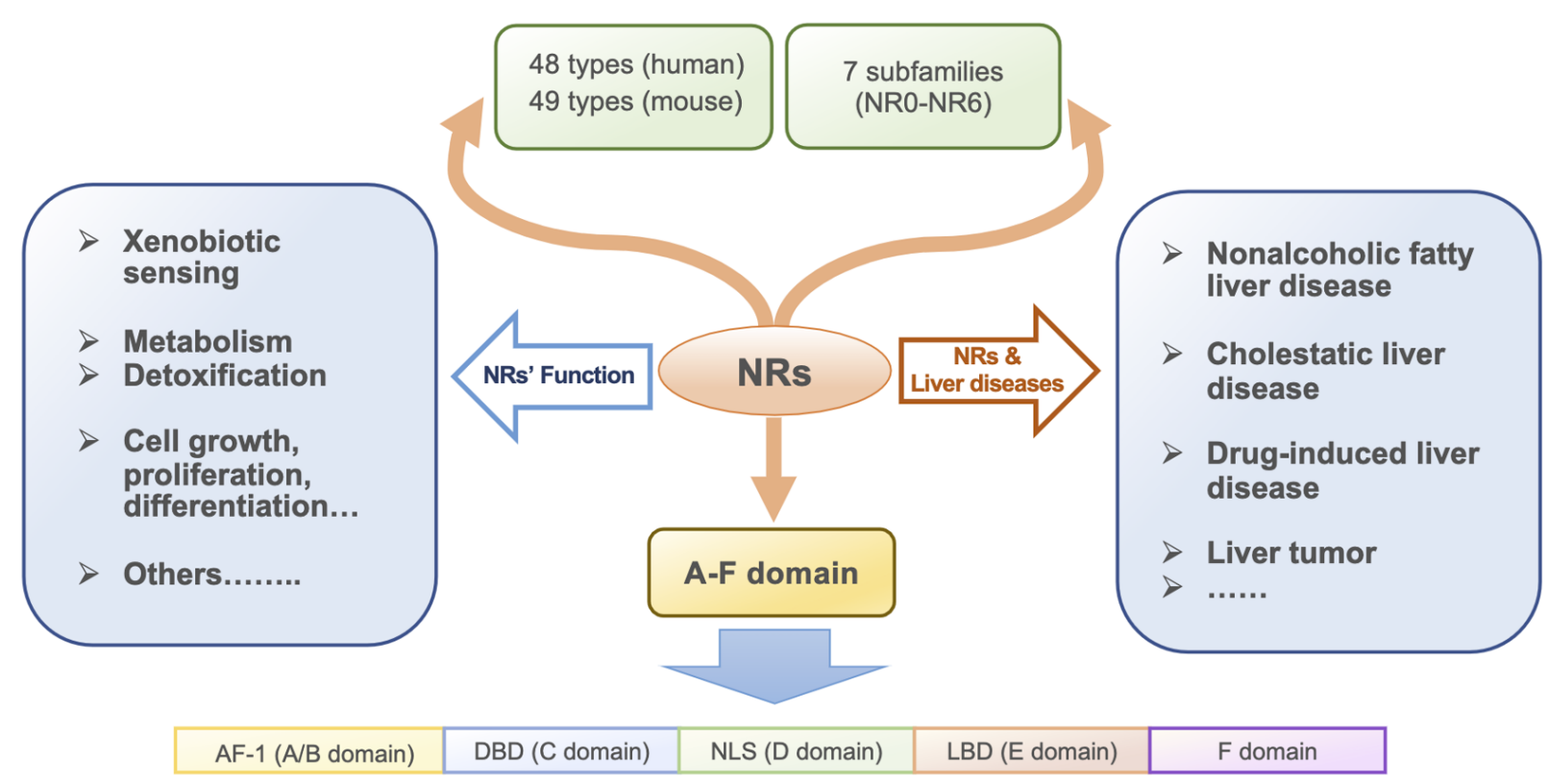


Figure 2

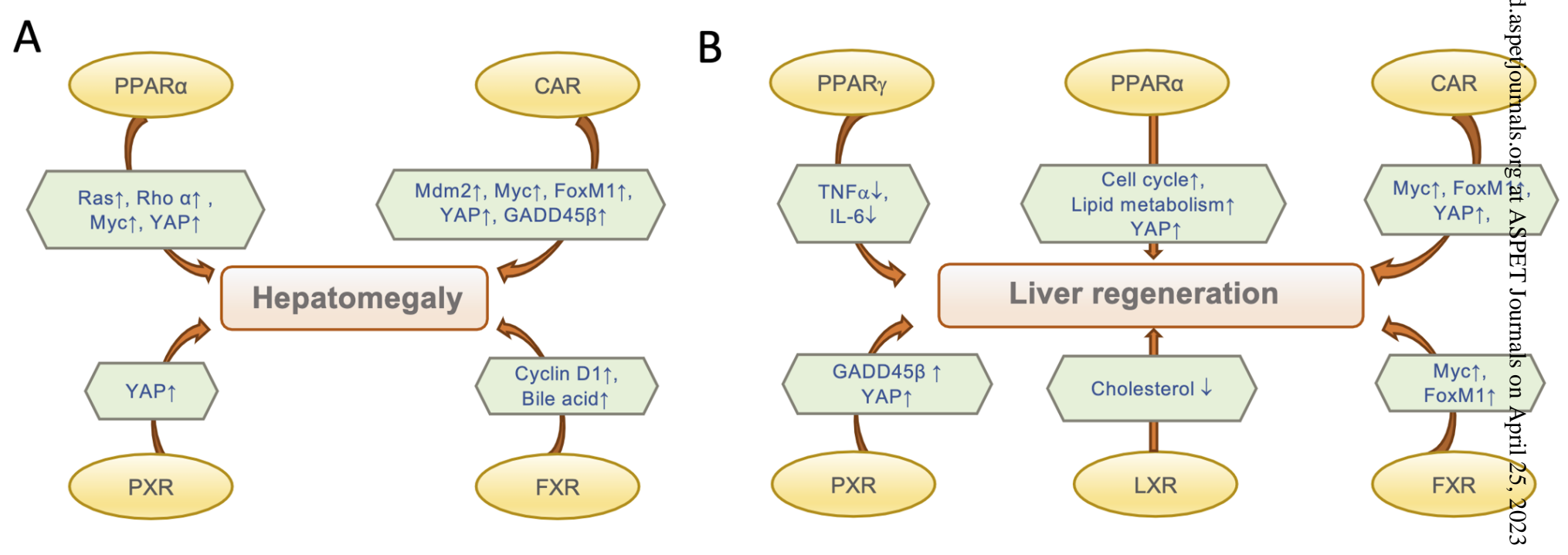




\section{Figure 3}

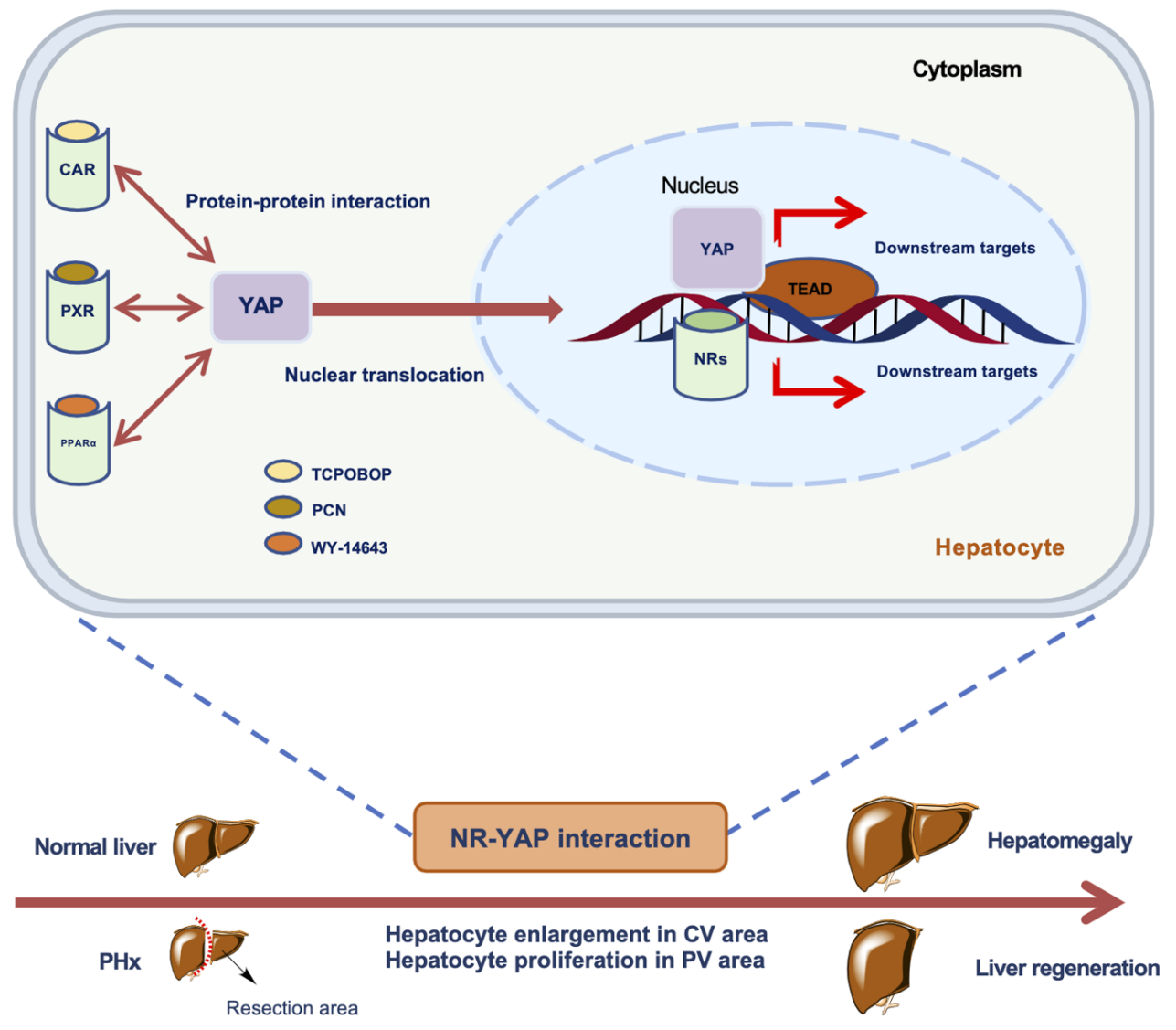

